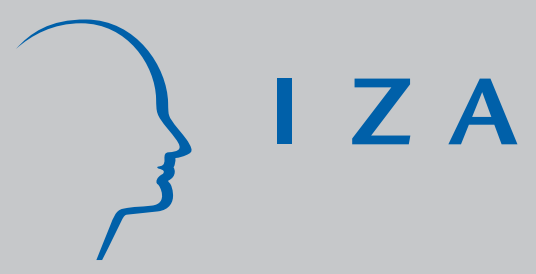

IZA DP No. 3296

The Linkages between FDI and Domestic Investment: Unravelling the Developmental Impact of Foreign Investment in Sub-Saharan Africa

Leonce Ndikumana

Sher Verick

J anuary 2008 


\title{
The Linkages between FDI and Domestic Investment: Unravelling the Developmental Impact of Foreign Investment in Sub-Saharan Africa
}

\author{
Leonce Ndikumana \\ University of Massachusetts, Amherst \\ and UNECA \\ Sher Verick \\ UNECA and IZA
}

Discussion Paper No. 3296

January 2008

IZA

P.O. Box 7240

53072 Bonn

Germany

Phone: +49-228-3894-0

Fax: +49-228-3894-180

E-mail: iza@iza.org

Any opinions expressed here are those of the author(s) and not those of IZA. Research published in this series may include views on policy, but the institute itself takes no institutional policy positions.

The Institute for the Study of Labor (IZA) in Bonn is a local and virtual international research center and a place of communication between science, politics and business. IZA is an independent nonprofit organization supported by Deutsche Post World Net. The center is associated with the University of Bonn and offers a stimulating research environment through its international network, workshops and conferences, data service, project support, research visits and doctoral program. IZA engages in (i) original and internationally competitive research in all fields of labor economics, (ii) development of policy concepts, and (iii) dissemination of research results and concepts to the interested public.

IZA Discussion Papers often represent preliminary work and are circulated to encourage discussion. Citation of such a paper should account for its provisional character. A revised version may be available directly from the author. 
IZA Discussion Paper No. 3296

January 2008

\section{ABSTRACT \\ The Linkages between FDI and Domestic Investment: Unravelling the Developmental Impact of Foreign Investment in Sub-Saharan Africa}

While the recent increase in foreign direct investment (FDI) to African countries is a welcome development, the question remains as to the impact of these resource inflows on economic development. This study posits that a key channel of the impact of FDI on development is through its effects on domestic factor markets, especially domestic investment and employment. In this context, this study analyses the two-way linkages between FDI and domestic investment in Sub-Saharan Africa. The results suggest that firstly, FDI crowds in domestic investment, and secondly, countries will gain much from measures aimed at improving the domestic investment climate. Moreover, there are alternatives to resource endowments as a means of attracting foreign investment to non-resource rich countries.

JEL Classification: E22, F21, F23, O16

Keywords: $\quad$ FDI, private investment, public investment, Africa

Corresponding author:

Sher Verick

United Nations Economic Commission for Africa (UNECA)

Central Africa Office

P.O. Box 3005

Addis Ababa

Ethiopia

E-mail: sverick@uneca.org 


\section{Introduction}

The current debate on African economic development has devoted much attention to the role of external resource inflows, including foreign direct investment (FDI) and their potential contribution to accelerating growth and progress towards reaching development goals in Africa (UNECA, 2006). Recent evidence indicates that FDI to African countries has been on the rise, especially since the 1990s (Ndikumana, 2003; UNECA, 2006), consistent with the general trend of private capital flows in developing regions.

However, two main issues arise with regard to recent trends of FDI to Africa. First, although the volume of FDI to Africa has increased substantially since the 1990s, Africa remains largely marginalized in the context of financial globalisation. Though Africa's share in world FDI flows reached 3.1per cent in 2005, it is still less than half of the share reached in the 1970s. Therefore, to the extent that attracting more FDI remains a desirable objective, the first challenge is to make African countries more attractive to foreign investors. Second, despite the increase in private capital inflows, these resources have not had a meaningful impact on economic development in African countries. Thus the second challenge is how to increase the developmental impact of FDI in African economies.

This paper seeks to provide empirical evidence that sheds light on these two critical challenges faced by economies, focusing in particular on the sub-Saharan region. With regard to the first challenge, the study starts from the view that to design effective strategies for making Africa more competitive, it is essential to understand the drivers 
of FDI. This study contributes to the debate by providing further evidence on the determinants of FDI to African countries. A growing body of literature has uncovered a large range of determinants of FDI in developing countries in general, although relatively less is known for the specific case of African countries (see Asiedu, 2002, 2005).

A distinguishing feature of this study is the emphasis on the role of both domestic private and public investment in attracting private foreign capital. Though the literature also suggests that an investment-friendly labour market regulation should improve a country's position in the eyes of foreign investors, it is difficult to analyse this important dimension of domestic factor markets due to inadequate data. For this reason we focus on domestic investment as a determinant of FDI inflows. In this respect, a strong private investment record is likely to act as a signal of high returns to capital while adequate public infrastructure (through high public investment) reduces the cost of doing business, which raises the marginal return to FDI. This study seeks to provide evidence on these linkages with a view to shed light on strategies that may help African economies to increase private capital inflows.

With regard to the second challenge, the study posits that an important channel of the effects of FDI on development in the host economies is through synergies between FDI and domestic public and private investment. While FDI can stimulate growth, ${ }^{1}$ these growth effects are sustainable only if FDI stimulates the utilization of domestic factors of production, especially by increasing employment and stimulating private investment. This will complement other important effects of FDI on the domestic

\footnotetext{
${ }^{1}$ Some references for the evidence on the impact of FDI on growth include Ankilo (2003), BaliamouneLutz (2004); and Mold (2004).
} 
economy, including technological spillover effects and facilitating access to global markets. Thus, by empirically investigating the effects of FDI on domestic factor markets, this study contributes to uncovering the channels through which FDI can affect economic growth.

To empirically investigate the two questions, that is, the impact of domestic factor markets on FDI on the one hand and the effects of FDI on domestic factor markets on the other hand, we use a sample of 38 Sub-Saharan African countries for the period 1970-2005 (see Appendix I). We use two estimation methodologies to explore the robustness of the results: a robust OLS estimator controlling for outliers, which is an important issue given the high diversity across African countries; and a fixed-effects specification to take into account country-specific effects. We also explore the impact of resource-intensity by both including measures of resource endowment (share of resources in exports) in the equation and by estimating the equations by sub-samples classified by resource intensity following Collier and O’Connell (2006).

The results shed light on the two key questions investigated by this study. First, the evidence suggests a strong relationship between foreign direct investment and domestic investment. The relationship runs both ways, but the impact of private domestic investment on FDI is stronger and more robust than the reverse relation. This suggests that high domestic private investment is a signal for high returns to capital, which attracts foreign investment. Thus, efforts to improve incentives for private investment will pay off by, among other things, making African countries more competitive in the eyes of foreign investors. Public investment does not appear to be a 
major driver of FDI in these African countries, which may reflect the inefficiency of public infrastructure.

The remainder of the paper is organized as follows. Section 2 provides stylised facts on the trends of FDI relative to domestic investment in African countries. It also examines correlations between FDI and characteristics of domestic factor markets in addition to factors that have been identified in the literature as important determinants of FDI. Section 3 undertakes a detailed econometric investigation of the impact of domestic investment on FDI, taking into account other established correlates of FDI. Section 4 examines the effects of FDI on private investment. Section 5 summarizes the findings and concludes by highlighting key policy implications.

\section{FDI in sub-Saharan African countries: stylised facts}

\subsection{Trends in FDI and domestic investment in SSA}

In general, FDI in Sub-Saharan Africa (SSA) is low in comparison to other developing regions, concentrated in a few countries and largely targeting the natural resources sector. In recent years FDI flows to the region have been growing strongly in response to not only high commodity prices but also to improved macroeconomic stability. FDI inflows to SSA surpassed US\$20 billion in 2005, a 58.1 per cent increase on the previous year. As a result of this development, the region's share in global flows has increased from 0.5 per cent in 2000 to 2.2 per cent in 2005, though this remains far below the peak of 1970 (6.2\%) (Figure 1). The continuing low share for the region reflects the dominance of China and other emerging economies in attracting foreign investment since the 1980s. 
Figure 1: FDI to SSA: volume and share in world inflows, 1970 - 2005

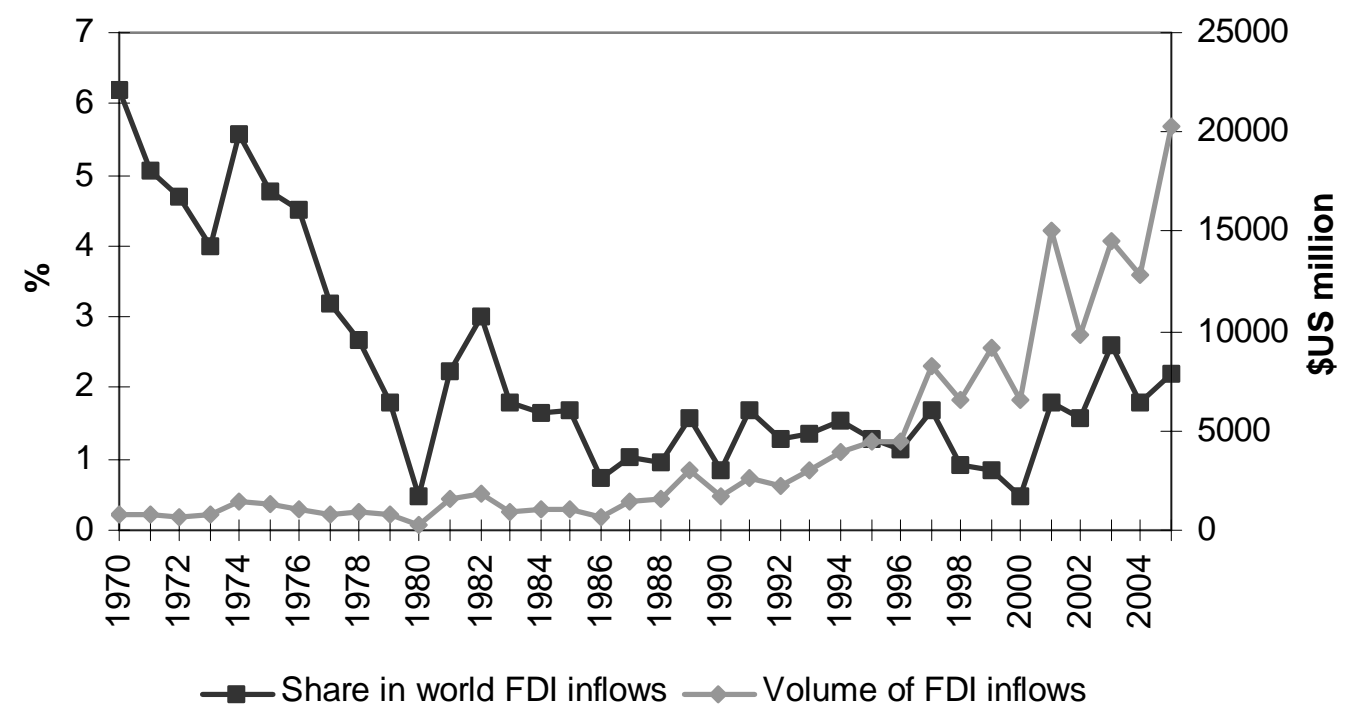

Source: UNCTAD, FDI online database.

Figure 2 displays the evolution of FDI inflows to the sample of 38 SSA countries used in this paper, in comparison to gross private and public investment as ratios of gross domestic product. As evident in this graph, FDI inflows have been increasing since the mid-1990s, peaking at 4.8 per cent of GDP in 2003. Gross private investment reached a maximum of 16.4 per cent of GDP in 1972 before declining to around 10 per cent in the early 1980s. Since the 1990s, private investment rates have been slowly increasing. In comparison, gross public investment peaked at around 14 per cent in 1976 before declining rapidly over the following decade and has stagnated at between 7 per cent and 8 per cent since 1984 .

The clear message from these trends is that while FDI is increasing in sub-Saharan African countries, domestic investment, particularly public investment, remains low and is not responding enough to the improvements in economic and political conditions observed on the continent over the past two decades (see also UNECA (2006)). 
Figure 2: Trends in FDI, private and public investment for 38 sub-Saharan African countries, 1970-2005

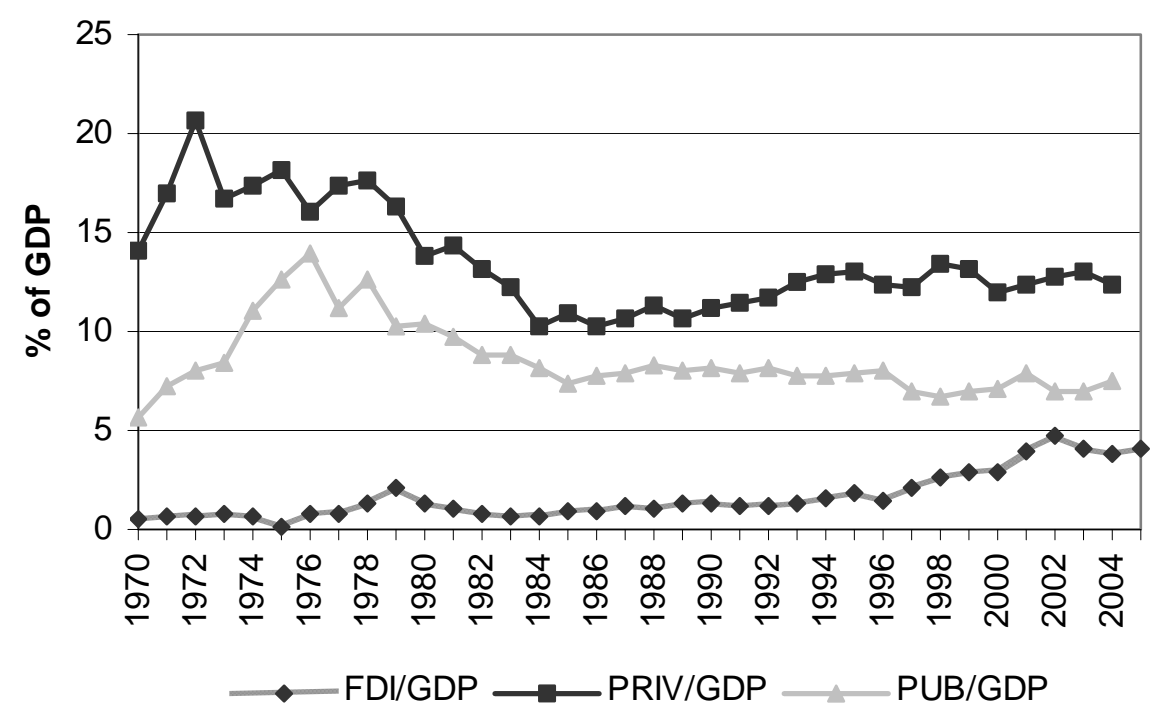

Notes: FDI/GDP = foreign direct investment/GDP; PRIV/GDP = gross private investment/GDP; PUB/GDP = gross public investment/GDP.

Source: UNCTAD, FDI online database; World Bank Africa Database 2006; World Development Indicators, online database.

Looking at the cross-country differences in these three dimensions of investment reveals significant variations across sub-Saharan countries (Table A1 in Appendix II). The countries with the highest average FDI/GDP ratios are Angola (6.9\%), Chad (6.2\%) and Seychelles (5.2\%). The high ratios for Chad and Angola represent recent investments in the natural resource sector. Burundi, Burkina Faso and surprisingly Kenya have the lowest average FDI inflows as a percentage of GDP, all with figures below 1 per cent. Overall, 15 out of the 38 countries in the sample have average ratios of less than 1 per cent of GDP.

In contrast, the largest private investment/GDP ratios are found in Lesotho (33.9\% of GDP), Gabon (23.2\%) and Botswana (21.2\%). Resource-rich countries like Angola have not yet translated their large export revenues into an increase in domestic private investment. Most of the countries with above average ratios of private investment are 
middle-income countries. Least-developed countries (LDCs) tend to have lower private investment rates, with Burundi, Niger and Central African Republic having the lowest ratios (less than $5 \%$ of GDP).

Finally, public investment, which is driven by very different factors than foreign and domestic private investment, also varies considerably across the sub-Saharan countries in the sample. The average ratio of gross public investment to GDP ranges from 2.5 per cent in Zimbabwe to 20.5 per cent in Guinea-Bissau.

The recent commodity price boom has fuelled a considerable inflow of FDI to the natural resource sector in a number of African countries. This is reflected in the average FDI inflows in addition to differences in private and public investment across the sample. The groupings used in this descriptive analysis and below in estimating the empirical models are based on Collier and O’Connell (2006) (see Appendix I for an explanation of these groupings). FDI as a ratio of GDP is accordingly higher in resource-intensive countries (Table 1). Interestingly, private investment is also higher, reflecting perhaps the impact of FDI on private investment in these countries. In contrast, public investment is marginally higher in non-resource-intensive countries.

Table 1: FDI, private and public investment by resource-intensity

\begin{tabular}{lccc}
\hline Grouping & FDI/GDP & $\begin{array}{c}\text { Private } \\
\text { investment/GDP }\end{array}$ & $\begin{array}{c}\text { Public } \\
\text { investment/GDP }\end{array}$ \\
\hline Full sample & 1.77 & 12.09 & 8.00 \\
Non-resource-intensive & 1.39 & 11.31 & 8.11 \\
Resource-intensive & 2.74 & 13.89 & 7.71 \\
\hline
\end{tabular}

Source: UNCTAD, FDI online database; World Bank Africa Database 2006. Notes: See Appendix I for an explanation of these groupings. 
Looking at these variables in these groupings reveals a couple trends (Figures 3 and 4). Firstly, as illustrated in Figure 3, FDI inflows have been in general higher and more volatile in resource-intensive countries, with a considerable divergence in recent years as a consequence of the commodity boom. This was also witnessed in the late 1970s. Note also that FDI inflows have been more volatile among resource-intensive countries. This may reflect the lumpiness of FDI in resource exploration and extraction, which results from the large fixed costs involved in such projects.

Figure 3: Trends in FDI by resource-intensity, 1970-2005

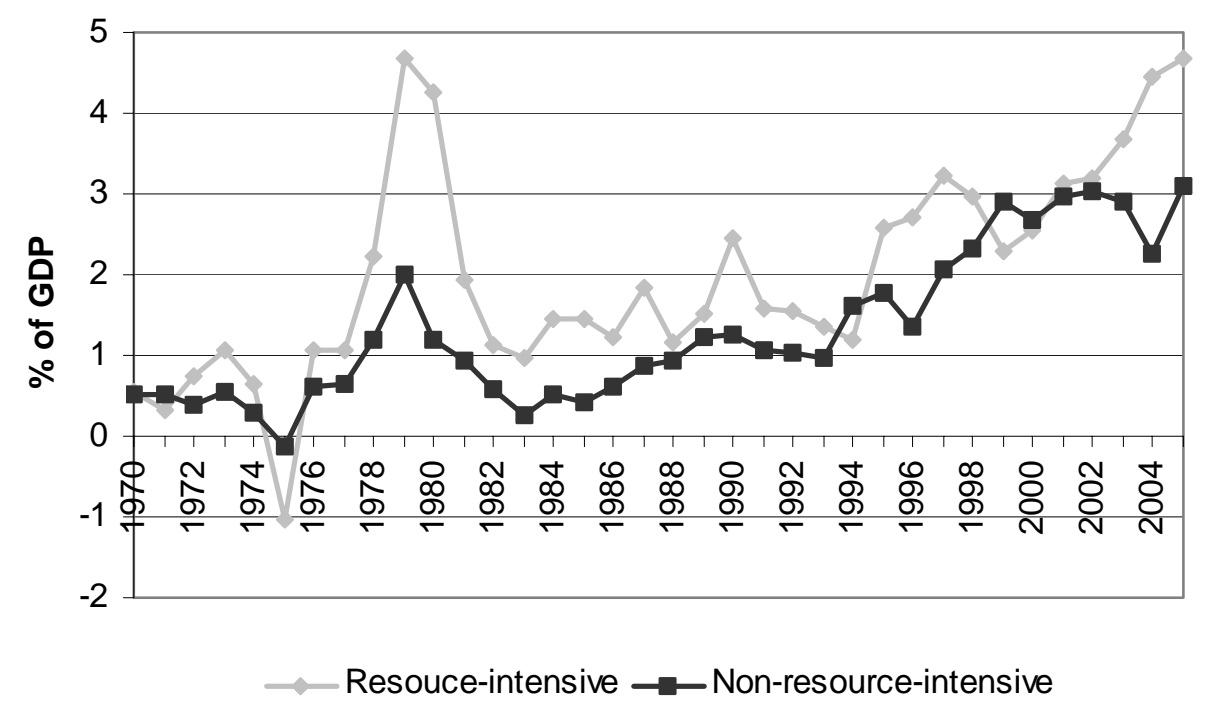

Source: UNCTAD, FDI online database; World Development Indicators, online database.

Turning to private investment (Figure 4) shows that higher rates of private investment in resource-intensive countries was only evident between 1970 and 1986, after which there has been considerable convergence of private investment across the two groups of countries. In comparison, the trends in public investment are not as different, with a slightly higher degree of volatility witnessed in non-resource-intensive countries. 
Figure 4: Trends in private and public investment by resource-intensity, 1970-2004

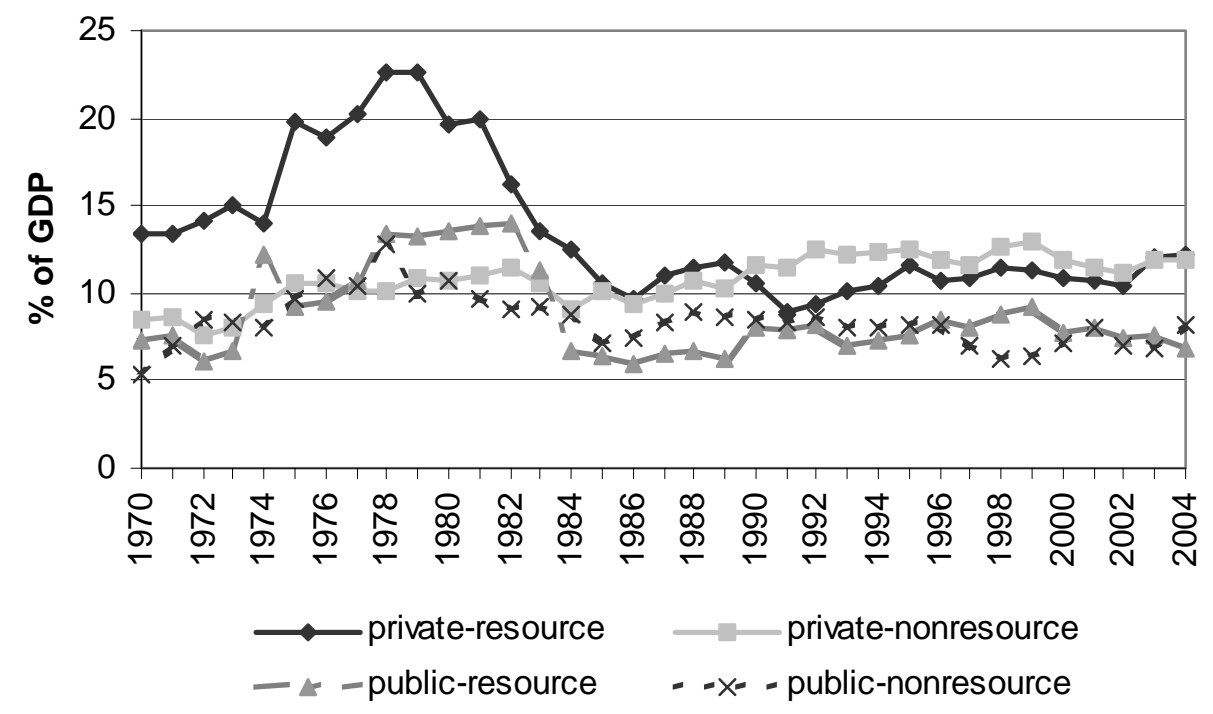

Notes: private-resource $=$ private investment/GDP in resource-intensive countries; privatenonresource $=$ private investment $/ \mathrm{GDP}$ in non-resource-intensive countries; public-resource $=$ public investment/GDP in resource-intensive countries; public-nonresource = public investment /GDP in non-resource-intensive countries.

Source: UNCTAD, FDI online database; World Bank Africa Database 2006; World Development Indicators, online database.

\subsection{The relationship between investment and key determinants}

In Section 3 we undertake a detailed econometric analysis of the determinants of FDI, with a particular focus on the role of domestic factor markets. In this section, we start by investigating correlations between FDI and characteristics of domestic factor markets as well as other determinants including macroeconomic, political, and human capital variables.

As can be seen in Table 2, FDI inflows are significantly and positively correlated with a range of determinants typically employed in the literature: GDP growth, openness as measured by total trade, infrastructure as measured by the number of telephone subscribers, natural resource endowment and the quality of polity (see, for e.g., Asiedu 2002, 2004, 2005; Dupasquier and Osakwe, 2006; Kandiero and Chitiga, 2006; Lydon 
and Williams, 2005; UNECA, 2006). A positive correlation is evident between FDI/GDP and the stock of FDI inflows, suggesting that foreign companies continue to invest in countries where they have a presence in addition to the attraction of other foreign entities to an established market that already caters for foreign investors.

Table 2: Correlations between FDI/GDP and key determinants

\begin{tabular}{lccc}
\hline Variable & $\begin{array}{c}\text { Pearson's correlation } \\
\text { coefficient }\end{array}$ & $\begin{array}{c}\text { No. Of } \\
\text { P-value }\end{array}$ \\
\hline observations \\
Openness & 0.11 & 0.00 & 1228 \\
Log of telephone subscribers & 0.35 & 0.00 & 1203 \\
Log of FDI stock & 0.24 & 0.00 & 1059 \\
Detrended REER & 0.30 & 0.00 & 939 \\
REER volatility & 0.02 & 0.58 & 644 \\
Detrended CPI & -0.16 & 0.00 & 644 \\
CPI volatility & -0.08 & 0.03 & 866 \\
Polity score & 0.21 & 0.00 & 866 \\
Oil, mineral and ore exports as \% & 0.07 & 0.02 & 1120 \\
of total merchandise exports & & & \\
Ogive concentration index & 0.13 & 0.00 & 595 \\
\hline
\end{tabular}

Source: Polity IV Project; UNCTAD, FDI online database; World Development Indicators, online database.

In terms of political variables, FDI inflows are positively correlated with a composite indicator of democracy and autocracy (polity2). ${ }^{2}$ This suggests that FDI inflows are higher in countries that are more democratic. However, looking at this combined polity score as a categorical variable rather than as a single indicator reveals that this correlation is not linear. As illustrated in Table 3, countries that are classified as weakly autocratic have the highest average FDI/GDP ratio. Based on the average score for the period 2000-2004, countries in this category include Angola, Chad, Republic of Congo and Gabon, where high FDI inflows are largely driven by natural resource extraction.

\footnotetext{
${ }^{2}$ See Marshall and Jaggers (2005) for detailed information on this polity indicator.
} 
In comparison, private investment is higher in strongly democratic countries, which underscores the importance of a supportive investment climate, including good governance and institutions, in promoting domestic private investment. On the other hand, public investment is higher in both strongly autocratic and strongly democratic countries, suggesting no clear relationship between public investment and the polity.

Table 3: Investment (\% of GDP) by political regimes

\begin{tabular}{lccc}
\hline Type of political regime & FDI/GDP & PRIV/GDP & PUB/GDP \\
\hline Strongly autocratic & 1.13 & 11.55 & 8.93 \\
Weakly autocratic & 2.76 & 12.08 & 6.21 \\
Weakly democratic & 1.41 & 10.38 & 7.21 \\
Strongly democratic & 1.94 & 13.85 & 8.44 \\
\hline
\end{tabular}

Source: Polity IV; UNCTAD, FDI online database; World Bank Africa Database 2006; World Development Indicators, online database.

FDI inflows are unsurprisingly also positively correlated with the proportion of natural resources in merchandise exports. Countries where oil, minerals and ore account for more than 50 per cent of merchandise exports have on average a FDI/GDP ratio of 2.1 per cent compared to 1.4 per cent for countries with lower shares of resources in exports. In these natural resource rich countries, private and public investment/ GDP ratios are also higher. This relationship is also captured by the positive correlation between FDI and the Ogive index of concentration of exports, implying that inflows are higher in countries with lower levels of export diversification. In fact, this result suggests that FDI may contribute to further concentration of production and exports, exposing the recipients further to export instability. 


\subsection{Relationship between FDI and domestic factor markets}

Turning to the main focus of this paper, we investigate the correlation between FDI and domestic factor markets. As evident in Table 4, FDI is positively correlated with a range of variables characterising the domestic factor markets.

Firstly, foreign investment is higher when both private and public investment ratios are higher, though the correlation is much higher in the case of private investment. This is a first indication of the important relationship between these three investment variables. In addition to the insight provided by these correlations, it is important to recognise that there variables are related over time in a dynamic relationship with causality running in both directions. These issues are investigated further in sections 3 and 4 below.

Table 4: Correlations between FDI and domestic factor market characteristics

\begin{tabular}{lccc}
\hline Variable & $\begin{array}{c}\text { Pearson's correlation } \\
\text { coefficient }\end{array}$ & $\begin{array}{c}\text { No. of } \\
\text { P-value }\end{array}$ & \begin{tabular}{c} 
observations \\
\hline Private investment/GDP
\end{tabular} \\
Public investment/GDP & 0.25 & 0.00 & 895 \\
Monthly manufacturing wage & 0.06 & 0.07 & 877 \\
Monthly manufacturing wage differential & 0.37 & 0.00 & 194 \\
Rigidity of employment index & 0.35 & 0.00 & 194 \\
Youth literacy rate & 0.10 & 0.34 & 90 \\
\hline
\end{tabular}

Source: UNCTAD, FDI online database; UNESCO Institute for Statistics, online database; World Bank Africa Database 2006; World Development Indicators, online database.

Secondly, there is also evidence of a large positive correlation between FDI inflows and monthly manufacturing wages, contrary to a negative relationship between labour costs and FDI implied by theory and as found in certain empirical studies. ${ }^{3}$ Moreover,

\footnotetext{
${ }^{3}$ Asiedu (2002) reports that different cross-country studies find that labour costs can have either a positive, negative or insignificant effect on FDI. However, Kucera (2002:4) argues that the evidence "leans towards suggesting that higher labour costs negatively affect FDI". The negative effects appear to be stronger in studies that have controlled for differences in labour productivity (Kucera, 2004).
} 
there is also a positive correlation between FDI and the wage differential, which is defined here as the difference between the country-level monthly manufacturing wage and the average in the sample for that year. This implies that countries that have above average wages tend to also have higher FDI/GDP ratios. As shown in some of the literature, this could be the result of foreign-owned firms paying a wage premium (see, for example, te Velde and Morrissey (2003) for evidence based on data from five African countries). Alternatively, foreign investors could be attracted to countries with higher levels of human capital, which is reflected in higher wages. Another possibility is that foreign investors are able to absorb high wage rates due to high returns to capital. The positive correlation between the wage rate and FDI is also consistent with the fact that FDI to Africa flows mostly into natural resource industries, which are capital intensive.

In addition to the direct cost of wages, the literature has investigated whether labour market regulations and the resulting rigidity in terms of hiring, firing, hours and other key factors deter foreign investors. For example, if legislation prevents or severely constrains the dismissal of workers, firms will have lower incentives in the first place to hire new employees. Such regulations could, at least theoretically, deter foreign companies from investing in a specific country (see OECD (2004) and UNECA (2006) for a further discussion on these issues).

However, empirical evidence on this relationship is mixed. Javorcik and Spatareanu (2005) find that greater labour market flexibility in the host country in absolute and relative terms is correlated with higher FDI flows. In contrast, Kucera (2002) finds no support for the hypothesis that foreign investors favour countries with lower labour 
standards, which suggests that the benefits of sound labour standards outweigh the costs. Although Africa has relatively rigid employment regulations in comparison to other developing regions, the correlation presented in Table 3 does not suggest any significant relationship between the rigidity of employment and FDI inflows.

Human capital is another important determinant of FDI inflows, as investigated by such studies as Noorbakhsh, Paloni and Youssef (2001), who find that this factor is one of the most important drivers of foreign investment. Contrasting this stylised fact, there is no statistical evidence of a positive correlation between FDI/GDP and the youth literacy rate in the case of the sample of African countries considered in this study (Table 4).

Table 5: Investment (\% of GDP) by level of youth literacy

\begin{tabular}{lcccc}
\hline Level of youth literacy & \multicolumn{1}{c}{$\begin{array}{c}\text { Private } \\
\text { investment }\end{array}$} & $\begin{array}{c}\text { Public } \\
\text { investment }\end{array}$ & $\begin{array}{c}\text { FDI stock } \\
\text { (US\$ millions) }\end{array}$ \\
\hline $\mathbf{1 9 7 0 - 2 0 0 5}$ & & & & \\
\hline $\begin{array}{l}\text { Low youth literacy rate (<25th percentile) } \\
\text { Medium youth literacy rate }\end{array}$ & 1.64 & 8.28 & 8.44 & 192.94 \\
$\begin{array}{l}\text { (25th percentile - 75th percentile) } \\
\text { High youth literacy rate (>75th percentile) }\end{array}$ & 1.53 & 10.37 & 7.68 & 1130.14 \\
\hline After 1997 & & & & 4128.12 \\
\hline Low youth literacy rate (<25th percentile) & 7.68 & 12.74 & 9.08 & 541.61 \\
$\begin{array}{l}\text { Medium youth literacy rate } \\
\text { (25th percentile - 75th percentile) }\end{array}$ & 2.62 & 10.47 & 6.99 & 1651.93 \\
High youth literacy rate (>75th percentile) & 3.25 & 13.37 & 6.09 & 7047.04 \\
\hline
\end{tabular}

Source: UNCTAD, FDI online database; UNESCO Institute for Statistics online database; World Bank Africa Database 2006; World Development Indicators, online database

If we look at investment ratios by various percentiles in the distribution of youth literacy rate in the sample, a different relationship emerges. Firstly, as displayed in Table 5, FDI inflows, the stock of FDI, and private investment are higher in countries with higher youth literacy rates (this includes countries like Botswana, Namibia and South Africa), while public investment is the lowest in such countries. 
Restricting the sample to post-1997, a period where FDI inflows have accelerated, provides evidence of another relationship. In this case, FDI is considerably higher in countries with low literacy rates $(<46 \%)$. This category includes countries such as Chad where oil exploration and exploitation have attracted large FDI inflows. This does not imply that human capital is not an important driver of FDI in African countries. Rather, as clearly evidenced by the positive and increasing relationship between literacy rate category and stock of FDI, human capital is important for sustaining foreign investment over the longer term.

\section{Econometric analysis of the linkages between domestic investment and FDI}

The summary statistics presented above provide an insight into the relationship between foreign investment and a range of structural or fundamental factors, in addition to the correlations with domestic factor markets. In this section, we investigate the impact of the variables discussed above on FDI inflows and private investment, controlling for outliers, unobserved heterogeneity and endogeneity of variables, which can bias estimates. The analysis is based on the following specification:

$$
\frac{F D I}{G D P}_{i t}=\alpha+\beta^{\prime} X_{i t}+\mu_{i}+\varepsilon_{i t}
$$

where $F D I / G D P$ is the net inflow of foreign direct investment as a ratio to real GDP, $X$

is a vector of determinants including domestic investment, $\mu_{i}$ the time-invariant unobserved heterogeneity term and $\varepsilon_{i t}$ the random error term. 


\subsection{Fundamental determinants of FDI}

As highlighted in Sections 1 and 2, the literature on FDI has identified a range of key determinants including economic growth, openness, and infrastructure. Our base empirical specification includes these variables in addition to the lagged stock of FDI to capture the impact of existing foreign investment on new FDI inflows. We also include a dummy for post-1997 to reflect the shift in the trend in FDI inflows. Dummies for Angola and Chad interacted with a dummy for the period after 1997 are also used in the empirical specifications to test the sensitivity of our results to the substantial rise in FDI/GDP ratios in these countries starting in the second half of the 1990s. Though the fixed-effects estimator removes the time-invariant country effect, it does not account for such a time-varying impact at the country-level. The estimates for equation (1) using the fixed-effects method and the robust OLS estimator where outliers have been weighted are reported in Table 6 . Column 4 reports the results with the Angola and Chad dummies and a post-1997 dummy.

The coefficient estimates reported in Table 6 are largely consistent with the results found in the literature. The robust OLS results in column (1) show that GDP growth, openness, and the stock of FDI all have a large positive effect on FDI inflows. The structural break dummy capturing the shift in the trend after 1997 has the expected positive effect on FDI inflows. Contrary to expectations, the coefficient on the infrastructure variable (log of telephone subscribers) is negative. This may reflect the fact that the resource-rich countries that have attracted FDI also have an underdeveloped telecommunication network. It is also possible that FDI inflows to Sub-Saharan Africa are being attracted by opportunities in the undeveloped telecommunications sector in many countries, suggesting reverse causality. However, 
in the case of the fixed effects regression (columns 2 and 3) the coefficient on this variable becomes positive and significant, suggesting that the correlation with the unobserved country time-invariant heterogeneity $\left(\mu_{\mathrm{i}}\right)$ was causing a bias in the OLS estimates.

Table 6: Structural determinants of FDI: contemporaneous effects

\begin{tabular}{lccc}
\hline Dependent variable: FDI/GDP & & & \\
& OLS & FE & FE \\
Explanatory variables & $\mathbf{( 1 )}$ & $\mathbf{( 2 )}$ & $\mathbf{( 3 )}$ \\
\hline GDP growth & $0.019^{* *}$ & $0.040^{* *}$ & 0.018 \\
& $(0.009)$ & $(0.017)$ & $(0.016)$ \\
Openness & $0.020^{* * *}$ & $0.038^{* * *}$ & $0.025^{* * *}$ \\
& $(0.002)$ & $(0.007)$ & $(0.006)$ \\
Log of telephone subscribers & $-0.100^{* *}$ & $0.319^{*}$ & $0.434^{* *}$ \\
& $(0.047)$ & $(0.170)$ & $(0.156)$ \\
Log of stock of FDI inflows (t-1) & $0.213^{* * *}$ & $0.617^{* * *}$ & $0.545^{* * *}$ \\
& $(0.035)$ & $(0.158)$ & $(0.144)$ \\
Post-1997 & $0.945^{* * *}$ & $0.832^{* *}$ & 0.272 \\
& $(0.131)$ & $(0.348)$ & $(0.320)$ \\
Chad*Post-1997 & & & $10.453^{* * *}$ \\
& & & $(1.189)$ \\
Angola*Post-1997 & & & $12.386^{* * *}$ \\
& & & $(1.206)$ \\
\hline $\mathrm{R}^{2}$ & 0.30 & 0.21 & 0.37 \\
F-Statistic & $74.59^{* * *}$ & $47.15^{* * *}$ & $65.76^{* * *}$ \\
No. of observations & 868 & 867 & 868 \\
\hline
\end{tabular}

Notes: Standard errors reported in parentheses; *** - significant at the 1 per cent level, ** significant at the 5 per cent level, and * - significant at the 10 per cent level; OLS = robust OLS regression where outliers are weighted; $\mathrm{FE}=$ fixed effects regression. The $\mathrm{R}$-squared reported for the fixed-effects model is the overall statistic.

As an alternative way of controlling for potential simultaneity bias, we estimate equation (1) using lagged explanatory variables. The results for this specification are listed in Table 7, which are in line with those reported above in Table 6.

As reported in column 3, the estimates from the specification with the dummies for Angola and Chad are similar to column 2, expect for the number of telephone subscribers which becomes positive and significant as expected. 
The results in Tables 6 and 7 suggest that the positive effects of structural factors such as GDP, openness and telecommunications infrastructure are robust to any possible simultaneity of the relationship between these factors and FDI.

Table 7: Fundamental determinants of FDI, lagged effects

\begin{tabular}{lccc}
\hline Dependent variable: FDI/GDP & & & \\
& OLS & FE & FE \\
Explanatory variables & $(\mathbf{1})$ & $\mathbf{( 2 )}$ & $\mathbf{( 3 )}$ \\
\hline GDP growth (t-1) & $0.020^{* *}$ & $0.061^{* * *}$ & $0.041^{* *}$ \\
& $(0.009)$ & $(0.019)$ & $(0.017)$ \\
Openness (t-1) & $0.022^{* * *}$ & $0.033^{* * *}$ & $0.016^{* *}$ \\
& $(0.002)$ & $(0.007)$ & $(0.007)$ \\
Log of telephone subscribers (t-1) & $-0.158^{* * *}$ & 0.300 & $0.373^{* *}$ \\
& $(0.048)$ & $(0.199)$ & $(0.178)$ \\
Log of stock of FDI inflows (t-1) & $0.246^{* * *}$ & $0.711^{* * *}$ & $0.649^{* * *}$ \\
& $(0.036)$ & $(0.178)$ & $(0.159)$ \\
Post-1997 & $0.971^{* * *}$ & $0.980^{* * *}$ & 0.401 \\
& $(0.128)$ & $(0.373)$ & $(0.336)$ \\
Chad*Post-1997 & & & $10.236^{* * *}$ \\
& & & $(1.350)$ \\
Angola*Post-1997 & & & $16.381^{* * *}$ \\
& & & $(1.276)$ \\
\hline $\mathrm{R}^{2}$ & 0.31 & 0.18 & 0.39 \\
F-Statistic & $76.90^{* * *}$ & $39.50^{* * *}$ & $66.04 * * *$ \\
No. of observations & 869 & 869 & 869 \\
\hline
\end{tabular}

Notes: Standard errors reported in parentheses; *** - significant at the 1 per cent level, ** significant at the 5 per cent level, and * - significant at the 10 per cent level; OLS = robust OLS regression where outliers are weighted; FE = fixed effects regression. The R-squared reported for the fixed-effects model is the overall statistic.

\subsection{Macroeconomic variables, political instability and natural resources as determinants of FDI}

In addition to the above determinants of FDI inflows, additional variables such macroeconomic fundamentals, political stability, and natural resources have proven to be important drivers of foreign investment (see Asiedu (2005)). 
The results presented in Table 8 show that, consistent with theory and existing evidence, inflation ${ }^{4}$ and instability in prices are deterrents for FDI inflows to SubSaharan Africa. However, the results do not confirm the expected negative effect of exchange rate instability on FDI. This again may illustrate the particular situation in Africa where FDI is predominantly resource-seeking and highly profitable and thus offsetting the costs due to exchange rate instability. However, this result no longer holds for the specification with the Angola and Chad dummies (not reported here for reason of space).

In terms of political regime, the fixed-effects estimates in Table 8 (column 6) indicate that countries that have either strongly or weakly democratic governments attract lower FDI inflows than countries that are strongly autocratic. This latter group includes resource-rich countries such as Nigeria. Rather than suggesting that promoting democracy doesn't help attract foreign investors, this result reflects that natural resource rich countries tend to be more autocratic. In this respect, both the OLS and fixed-effects results (columns 7 and 8) unsurprisingly indicate that countries with a higher share of oil, mineral and ore in total merchandise exports tend to have higher FDI/GDP ratios. The results using the Ogive concentration index are very similar (these estimates are not reported in Table 8 for reason of space).

\footnotetext{
${ }^{4}$ Using the Angola and Chad dummies (interacted with the post 1997 dummy) results in a positive coefficient on the instability of consumer prices.
} 
Table 8: Macroeconomic, political and natural resource determinants of FDI inflows

\begin{tabular}{|c|c|c|c|c|c|c|c|c|}
\hline \multicolumn{9}{|c|}{ Dependent variable: FDI/GDP } \\
\hline & OLS & FE & OLS & FE & OLS & FE & OLS & FE \\
\hline $\begin{array}{l}\text { Explanatory } \\
\text { variables }\end{array}$ & (1) & (2) & (3) & & (5) & (6) & & (8) \\
\hline GDP growth & $0.019 * *$ & $0.041^{* *}$ & $0.026 * *$ & 0.030 & $0.017 *$ & $0.048 * * *$ & $0.060 * * *$ & 0.009 \\
\hline & $(0.009)$ & $(0.021)$ & $(0.010)$ & $(0.022)$ & $(0.009)$ & $(0.018)$ & $(0.020)$ & $(0.023)$ \\
\hline Openness & $\begin{array}{c}0.015^{* * *} \\
(0.002)\end{array}$ & $\begin{array}{c}0.044 * * * \\
(0.010)\end{array}$ & $\begin{array}{c}0.019 * * * \\
(0.002)\end{array}$ & $\begin{array}{c}0.038 * * * \\
(0.009)\end{array}$ & $\begin{array}{c}0.019 * * * \\
(0.002)\end{array}$ & $\begin{array}{c}0.043 * * * \\
(0.007)\end{array}$ & $\begin{array}{c}0.023 * * * \\
(0.003)\end{array}$ & $\begin{array}{c}0.022^{* * *} \\
(0.007)\end{array}$ \\
\hline Log of telephone & $-0.312^{* * *}$ & $0.564^{* *}$ & $-0.228 * * *$ & 0.122 & $-0.226^{* * *}$ & $0.451^{* * *}$ & -0.027 & 0.023 \\
\hline subscribers & $(0.052)$ & $(0.233)$ & $(0.055)$ & $(0.194)$ & $(0.050)$ & $(0.191)$ & $(0.082)$ & $(0.180)$ \\
\hline Log of stock of & $0.268 * * *$ & $0.937 * * *$ & $0.250 * * *$ & $0.667 * * *$ & $0.241 * * *$ & $0.638 * * *$ & $0.147 * *$ & $0.740 * * *$ \\
\hline FDI inflows (t-1) & $(0.038)$ & $(0.231)$ & $(0.037)$ & $(0.186)$ & $(0.034)$ & $(0.173)$ & $(0.068)$ & $(0.185)$ \\
\hline Post-1997 & $\begin{array}{c}0.974 * * * \\
(0.146)\end{array}$ & $\begin{array}{c}0.548 \\
(0.407)\end{array}$ & $\begin{array}{c}1.139 * * * \\
(0.136)\end{array}$ & $\begin{array}{c}0.939 * * * \\
(0.403)\end{array}$ & $\begin{array}{c}0.908^{* * *} \\
(0.128)\end{array}$ & $\begin{array}{l}0.833^{* *} \\
(0.366)\end{array}$ & $\begin{array}{c}0.845^{* * *} \\
(0.194)\end{array}$ & $\begin{array}{c}0.301 \\
(0.310)\end{array}$ \\
\hline REER detrended & $\begin{array}{l}0.0002 \\
(0.001)\end{array}$ & $\begin{array}{c}0.005 \\
(0.003)\end{array}$ & & & & & & \\
\hline REER volatility & $\begin{array}{c}-0.0017 \\
(0.0015)\end{array}$ & $\begin{array}{l}0.012^{* *} \\
(0.005)\end{array}$ & & & & & & \\
\hline CPI detrended & & & $\begin{array}{c}-0.001^{* * * *} \\
(0.000)\end{array}$ & $\begin{array}{c}-0.002 * * * \\
(0.0007)\end{array}$ & & & & \\
\hline CPI volatility & & & $\begin{array}{c}0.004 * * * \\
(0.000)\end{array}$ & $\begin{array}{c}-0.006^{* * *} \\
(0.002)\end{array}$ & & & & \\
\hline $\begin{array}{l}\text { Weakly } \\
\text { autocratic }^{\text {b }}\end{array}$ & & & & & $\begin{array}{c}0.114 \\
(0.137)\end{array}$ & $\begin{array}{c}0.402 \\
(0.339)\end{array}$ & & \\
\hline $\begin{array}{l}\text { Weakly } \\
\text { democratic }\end{array}$ & & & & & $\begin{array}{l}0.294^{*} \\
(0.179)\end{array}$ & $\begin{array}{c}-0.799 * * \\
(0.392)\end{array}$ & & \\
\hline $\begin{array}{l}\text { Strongly } \\
\text { democratic }^{b}\end{array}$ & & & & & $\begin{array}{c}0.079 \\
(0.134)\end{array}$ & $\begin{array}{c}-1.069 * * * \\
(0.361)\end{array}$ & & \\
\hline $\begin{array}{l}\text { Oil, mineral \& ore } \\
\text { exports (\% of total } \\
\text { exports) }\end{array}$ & & & & & & & $\begin{array}{c}0.009 * * * \\
(0.003)\end{array}$ & $\begin{array}{l}0.014^{*} \\
(0.007)\end{array}$ \\
\hline $\mathrm{R}^{2}$ & 0.26 & 0.12 & 0.42 & 0.16 & 0.30 & 0.19 & 0.27 & 0.16 \\
\hline F-Statistic & $28.02^{* * *}$ & $20.63 * * *$ & $65.40^{* * *}$ & $24.85^{* * *}$ & $42.40 * * *$ & $28.34 * * *$ & $24.26 * * *$ & $15.26 * * *$ \\
\hline No. of obs. & 577 & 577 & 646 & 646 & 794 & 794 & 391 & 391 \\
\hline
\end{tabular}

Notes: Standard errors reported in parentheses; *** - significant at the 1 per cent level, ** significant at the 5 per cent level, and * - significant at the 10 per cent level;

OLS = robust OLS regression where outliers are weighted; $\mathrm{FE}=$ fixed effects regression. The

$\mathrm{R}$-squared reported for the fixed-effects model is the overall statistic.

\subsection{Domestic factor markets as determinants of FDI}

Having established the role of structural determinants of FDI, we now turn to examining whether domestic factor markets have an additional effect on FDI. Unfortunately, the lack of adequate data on labour market characteristics makes it difficult to undertake panel data econometrics. Therefore, we focus on the impact of domestic and public investment on FDI. We add indicators of these factors to the base equation including structural determinants. 
The estimates presented in Table 9 underscore the important relationship between FDI inflows and both private and public investment. Though the coefficient on public investment is larger in the OLS estimates (column 1), the fixed-effects estimator indicates a stronger impact of private investment on FDI inflows (column 2). This is evidence that higher levels of private investment can help attract FDI inflows, possibly due to a signalling effect as higher private investment is seen as an indication of high returns to capital. Higher levels of public investment, particularly in areas like infrastructure, is expected to reduce production and trade costs and hence provide a more profitable environment for foreign investors.

Given the importance of the commodity boom as a driver of FDI inflows and economic growth in general in Africa, it is important to investigate how the above results vary by resource intensity. To carry out this exercise, we split the sample again according to the groupings defined by Collier and O'Connell (2006) (see Appendix I for an explanation of these groupings).

Using this classification indicates that FDI inflows are driven by different factors in resource-rich countries in comparison to resource-poor economies. As displayed in Table 9, in non-resource-intensive countries, the coefficient estimate show that infrastructure is an important driver of FDI in non-resource sectors. The stock of FDI and private investment are also significant determinants of FDI inflows in these countries. In contrast, infrastructure does not appear to matter in resource-intensive countries. At the same time, openness of the country is important, which is consistent with FDI inflows in these countries being driven by the opportunity to export natural 
resources. The stock of FDI has a large correlation with FDI inflows, which captures both the attraction of new FDI to countries with existing investments and reinvested profits of transnational corporations returning as FDI inflows to the receiving country. Private investment is also significant in this sub-sample with an even larger coefficient than in the case of the non-resource-intensive group.

Table 9: Domestic investment as determinants of FDI inflows

\begin{tabular}{|c|c|c|c|c|}
\hline $\begin{array}{l}\text { Dependent variable: FDI/GDP } \\
\text { Explanatory variables }\end{array}$ & $\begin{array}{c}\text { Full sample } \\
\text { OLS } \\
\text { (1) }\end{array}$ & $\begin{array}{c}\text { Full sample } \\
\text { FE } \\
(2)\end{array}$ & $\begin{array}{c}\text { Non-resource intense } \\
\text { FE } \\
(3) \\
\end{array}$ & $\begin{array}{c}\text { Resource intense } \\
\text { FE } \\
\text { (4) }\end{array}$ \\
\hline GDP growth & $\begin{array}{c}0.025 * * \\
(0.010)\end{array}$ & $\begin{array}{c}0.048 * * \\
(0.019)\end{array}$ & $\begin{array}{c}0.021 \\
(0.015)\end{array}$ & $\begin{array}{c}0.056 \\
(0.054)\end{array}$ \\
\hline Openness & $\begin{array}{c}0.018 * * * \\
(0.002)\end{array}$ & $\begin{array}{c}0.029 * * * \\
(0.007)\end{array}$ & $\begin{array}{c}0.002 \\
(0.006)\end{array}$ & $\begin{array}{c}0.058 * * * \\
(0.019)\end{array}$ \\
\hline Log of telephone subscribers & $\begin{array}{c}-0.192 * * * \\
(0.052)\end{array}$ & $\begin{array}{c}0.477 * * \\
(0.201)\end{array}$ & $\begin{array}{c}0.552^{* * *} \\
(0.157)\end{array}$ & $\begin{array}{c}0.449 \\
(0.541)\end{array}$ \\
\hline Log of stock of FDI inflows (t-1) & $\begin{array}{c}0.246 * * * \\
(0.041)\end{array}$ & $\begin{array}{c}0.560^{* * *} \\
(0.183)\end{array}$ & $\begin{array}{c}0.480 * * * \\
(0.136)\end{array}$ & $\begin{array}{c}1.665^{* * *} \\
(0.581)\end{array}$ \\
\hline Post-1997 & $\begin{array}{c}1.012^{* * *} \\
(0.135)\end{array}$ & $\begin{array}{c}0.727 * * \\
(0.368)\end{array}$ & $\begin{array}{c}0.324 \\
(0.286)\end{array}$ & $\begin{array}{c}1.118 \\
(1.000)\end{array}$ \\
\hline Private investment/GDP & $\begin{array}{c}0.023 * * \\
(0.009)\end{array}$ & $\begin{array}{c}0.159 * * * \\
(0.026)\end{array}$ & $\begin{array}{c}0.044 * * \\
(0.022)\end{array}$ & $\begin{array}{c}0.291^{* * *} \\
(0.059)\end{array}$ \\
\hline Public investment/GDP & $\begin{array}{c}0.031 * * \\
(0.014)\end{array}$ & $\begin{array}{c}0.067 * * \\
(0.034)\end{array}$ & $\begin{array}{c}0.028 \\
(0.026)\end{array}$ & $\begin{array}{c}0.117 \\
(0.059)\end{array}$ \\
\hline $\mathrm{R}^{2}$ & 0.30 & 0.18 & 0.19 & 0.16 \\
\hline F-Statistic & $45.05 * * *$ & $36.58 * * *$ & $23.99 * * *$ & $19.66 * * *$ \\
\hline No. of obs. & 748 & 748 & 540 & 208 \\
\hline
\end{tabular}

Notes: Standard errors reported in parentheses; *** - significant at the 1 per cent level, ** significant at the 5 per cent level, and * - significant at the 10 per cent level;

OLS = robust OLS regression where outliers are weighted; FE = fixed effects regression. The

$\mathrm{R}$-squared report for the fixed-effects model is the overall statistic.

\section{Impact of FDI on domestic investment}

Section 3 has provided an insight into how domestic investment affects foreign investment in a sample of 38 Sub-Saharan African countries. The relationship between FDI and domestic investment is likely to be bi-directional with FDI inflows also having an impact on factor markets. The most debated aspect of this relationship is 
whether foreign investment crowds in or crowds out domestic activity. This has been investigated by a range of studies, including some on Africa, which generally find that the effect is mostly neutral (see Agosin and Machado, 2005; UNCTAD, 2003; UNECA, 2006; and other references therein). This section explores this relation in the case of African countries. The analysis in this section is based on the following specification:

$$
\frac{P R I V}{G D P}_{i t}=\gamma+\zeta^{\prime} W_{i t}+\theta \frac{F D I}{G D P}_{i t}+\lambda \frac{P U B}{G D P}_{i t}+\xi_{i}+v_{i t},
$$

where $P R I V / G D P$ is private investment as a ratio to real GDP, FDI/GDP is the net inflow of foreign direct investment as a ratio to real $G D P, P U B / G D P$ is public investment as a ratio to real $G D P, W$ is a vector of other determinants of private investment, while $\xi_{i}$ is the time-invariant unobserved heterogeneity term and $v_{i t}$ is the random error term.

Using this specification and controlling for country-specific effects, there is evidence of a positive impact of FDI on private investment, suggesting crowding-in of private investment by FDI (Table 10). Public investment doesn’t appear to affect private investment once country-specific effects are accounted for. A strong and volatile exchange rate reduces the private investment rate, which probably reflects the negative effects of an overvalued exchange rate on the investment decisions of export-oriented firms (columns 3 and 4).

As found with in the case of FDI, the estimates for the determinants of private investment vary across countries by resource-intensity. Before looking at the differences, however, FDI appears to crowd in private investment in both resource-rich and resource-poor countries (columns 4 and 5, respectively). In comparison, public 
investment crowds out private investment in resource-intensive countries, but crowds in private activity in non-resource intensive economies. Growth in GDP only has a positive impact on private investment in the case of resource rich countries. In contrast to the results for FDI (Table 9), openness is only significant in the non-resourceintensive countries, which implies that private investment in these economies is nonetheless very much driven by trade. In both samples, there appears to be no correlation between private investment and the level of infrastructure as measured by the number of telephone subscribers.

Table 10: The determinants of private investment

\begin{tabular}{|c|c|c|c|c|c|}
\hline \multicolumn{6}{|c|}{ Dependent variable: Private investment/GDP } \\
\hline & $\begin{array}{c}\text { Full } \\
\text { sample }\end{array}$ & $\begin{array}{c}\text { Full } \\
\text { sample }\end{array}$ & $\begin{array}{c}\text { Full } \\
\text { sample }\end{array}$ & $\begin{array}{c}\text { Resource- } \\
\text { intense }\end{array}$ & $\begin{array}{c}\text { Non- } \\
\text { resource } \\
\text { intense }\end{array}$ \\
\hline Explanatory variables & $\begin{array}{c}\text { OLS } \\
\text { (1) }\end{array}$ & $\begin{array}{l}\text { FE } \\
\text { (2) }\end{array}$ & $\begin{array}{l}\text { FE } \\
\text { (3) }\end{array}$ & $\begin{array}{l}\text { FE } \\
\text { (4) }\end{array}$ & $\begin{array}{l}\text { FE } \\
(5)\end{array}$ \\
\hline FDI/GDP & $\begin{array}{c}-0.079 \\
(0.051)\end{array}$ & $\begin{array}{c}0.359 * * * \\
(0.057)\end{array}$ & $\begin{array}{c}0.398 * * * \\
(0.053)\end{array}$ & $\begin{array}{c}0.311^{* * *} \\
(0.095)\end{array}$ & $\begin{array}{c}0.387 * * * \\
(0.085)\end{array}$ \\
\hline Public investment/GDP & $\begin{array}{c}-0.184 * * * \\
(0.040)\end{array}$ & $\begin{array}{c}-0.050 \\
(0.050)\end{array}$ & $\begin{array}{c}0.043 \\
(0.053)\end{array}$ & $\begin{array}{c}-0.106^{* *} \\
(0.053)\end{array}$ & $\begin{array}{l}0.214^{*} \\
(0.126)\end{array}$ \\
\hline GDP growth & $\begin{array}{c}0.098 * * * \\
(0.031)\end{array}$ & $\begin{array}{c}0.046 \\
(0.029)\end{array}$ & $\begin{array}{c}0.026 \\
(0.028)\end{array}$ & $\begin{array}{l}-0.002 \\
(0.032)\end{array}$ & $\begin{array}{c}0.199 * * * \\
(0.063)\end{array}$ \\
\hline Openness & $\begin{array}{c}0.049 * * * \\
(0.006)\end{array}$ & $\begin{array}{c}0.060 * * * \\
(0.012)\end{array}$ & $\begin{array}{c}0.045^{* * *} \\
(0.014)\end{array}$ & $\begin{array}{c}0.065^{* * *} * \\
(0.013)\end{array}$ & $\begin{array}{c}0.034 \\
(0.023)\end{array}$ \\
\hline Log of telephone subscribers & $\begin{array}{c}1.017 * * * \\
(0.128)\end{array}$ & $\begin{array}{c}0.032 \\
(0.187)\end{array}$ & $\begin{array}{l}-0.325 \\
(0.234)\end{array}$ & $\begin{array}{c}0.271 \\
(0.213)\end{array}$ & $\begin{array}{c}-0.540 \\
(0.398)\end{array}$ \\
\hline REER detrended & & & $\begin{array}{c}-0.011^{* *} \\
(0.005)\end{array}$ & & \\
\hline REER volatility & & & $\begin{array}{c}-0.036 * * * \\
(0.007)\end{array}$ & & \\
\hline $\mathrm{R}^{2}$ & 0.28 & 0.21 & 0.14 & 0.29 & 0.03 \\
\hline F-Statistic & $60.77 * * *$ & $21.58 * * *$ & $26.65^{* * *}$ & $11.66^{* * *}$ & $12.41 * * *$ \\
\hline No. of obs. & 806 & 806 & 536 & 582 & 224 \\
\hline
\end{tabular}

Notes: Standard errors reported in parentheses; *** - significant at the 1 per cent level, ** _ significant at the 5 per cent level, and * - significant at the 10 per cent level OLS = robust OLS regression where outliers are weighted; FE = fixed effects regression. The $\mathrm{R}$-squared reported for the fixed-effects model is the overall statistic. 


\section{Conclusion}

The objective of this study was to contribute to the literature on the causes and effects of FDI in African economies by focusing on the linkages between FDI and domestic factor markets. In particular, the study investigated whether domestic investment promotes FDI inflows and is in turn affected by FDI. While the literature has provided much evidence on the determinants of FDI (although much less is still known in the case of African countries) and the effects of FDI on growth, very little is know about how FDI itself affects domestic factor markets. Understanding the linkages between FDI and factor markets is key to uncovering the channels through which FDI affects economic performance, which helps to identify the policy levers that may be activated to maximize both FDI inflows and the gains from FDI for the host economy. This paper attempted to fill this gap.

The empirical results in this study show that the relationship between FDI and domestic investment runs both ways, especially in the case of private investment. FDI crowds in private investment in this sample of SSA countries. The evidence supports the view that one way in which FDI can have a positive impact on growth is by enhancing domestic capital accumulation. However, the results also clearly indicate that the impact of private investment on FDI is stronger and more robust than the reverse relation. This result has important policy implications. In particular, the evidence suggests that African countries will benefit from measures aimed at promoting domestic private investment given that a strong investment performance will serve as a sign of high returns to capital, which in turn will attract more foreign 
capital. National policies should aim at harnessing complementarities between domestic private investment and FDI rather than regarding them as substitutes.

The analysis in this study also documents the importance of resource endowment as a driver of FDI. The results suggest that FDI is driven by different factors in resourceintensive relative to non-resource-intensive countries. In particular, infrastructure is critical for attracting FDI in non-resource rich countries but not in those with resources. This suggests that non-resource rich countries have to work harder to entice foreign investors. At the same time, this also implies that there are alternatives to resource endowments as a means of attracting foreign investment. Thus, by designing the right policy frameworks, African countries can make progress in overcoming marginalisation in the global economy. 


\section{References}

Agosin, M.R. and Machado, R. (2005) FDI in developing countries: does it crowd in domestic investment? Oxford Development Studies, 33(2), pp.149-162.

Ankilo, A.E. (2003) Foreign direct investment and economic growth in Sub-Saharan Africa. International Review of Economics and Business, 50(4), pp.569-580.

Asiedu, E. (2002) On the determinants of foreign direct investment to developing countries: is Africa different? World Development, 30(1), pp.107-119.

Asiedu, E. (2004) The Determinants of Employment of Affiliates of U.S. Multinational Enterprises in Africa. Development Policy Review, 22(4), pp.371-379.

Asiedu, E. (2005) Foreign Direct Investment in Africa: The Role of Natural Resources, Market Size, Government Policy, Institutions and Political Instability. The World Economy, 29(1), pp.63-77.

Baliamoune-Lutz, M. N. (2004) Does FDI contribute to economic growth? Business Economics, 39(2), pp.49-56.

Breitung, J. and Pesaran, M.H. (2005) Unit roots and cointegration in panels, Deutsche Bundesbank Discussion Paper, Series 1 - Economic Studies, No.42/2005.

Collier, P. and O’Connell, S. (2006) Opportunities and Choices, in: Explaining African Economic Growth, (Oxford: Centre for Study of African Economies).

Dupasquier, C. and Osakwe, P. (2006) FDI in Africa: performance, challenges and responsibilities. Journal of Asian Economies, 17(2), pp.241-260.

Javorcik, B.S. and Spatareanu, M. (2005) Do foreign investors care about labour market regulations? Rutgers University Newark Working Paper, No.2005-005.

Kandiero, T. and Chitiga, M. (2006) Trade openness and FDI in Africa. South African Journal of Economic and Management Sciences, 9(3), pp.355-370.

Konya, L. (2001) Panel data unit root tests with an application. Victoria University Working Paper.

Kucera, D. (2002) Core labour standards and foreign direct investment. International Labour Review, 141(1-2), pp.31-69.

Lydon, R. and Williams, M. (2005) Communications networks and FDI in developing countries. Communications and Strategies, 58, pp.43-60.

Marshall, M.G. and Jaggers, K. (2005) Polity IV Project: Political Regime Characteristics and Transitions, 1800-2004 - Dataset Users’ Manual. Polity IV Project. 
Mold, A. (2004) FDI and poverty reduction: a critical reappraisal of the arguments. Région et Développement, Special issue, 0(20), pp.91-122.

Ndikumana, L. (2003) Capital Flows, Capital Account Regimes, and Foreign Exchange Rate Regimes in Africa, in: United Nations Conference on Trade and Development (UNCTAD) Management of Capital Flows: Comparative Experiences and Implications for Africa, (Geneva: UNCTAD), pp.313-384.

Noorbakhsh, F., Paloni, A. and Youssef, A. (2001) Human capital and FDI inflows to developing countries: new empirical evidence. World Development, 29(9), pp.15931610.

Organisation for Economic Co-operation and Development (OECD) (2004) OECD Employment Outlook 2004 - Reassessing the OECD Jobs Strategy (Paris: OECD).

Spiezia, V. (2004) Trade, foreign direct investment and employment: some empirical evidence, in: Lee, E. and Vivarelli, M. (eds) Understanding Globalization, Employment and Poverty Reduction (New York: Palgrave Macmillan).

Te Velde, D.W. and Morrissey, O. (2003) Do workers in Africa get a wage premium if employed in firms owned by foreigners? Journal of African Economies, 12(1), pp.4173.

United Nations Conference on Trade and Development (UNCTAD) (2003) World Investment Report 2003 - FDI Policies for Development: National and International Perspectives (Geneva: UNCTAD).

UNCTAD (2007) FDI Online Database, http://stats.unctad.org/FDI//.

United Nations Economic Commission for Africa (UNECA) (2006) Economic Report on Africa: Capital Flows and Development Financing in Africa (Addis Ababa: UNECA).

United Nations Economic Commission for Africa (UNECA) (2007) Economic Report on Africa: Accelerating Africa's Development through Diversification (Addis Ababa: UNECA).

United Nations Educational, Scientific and Cultural Organization (UNESCO) Institute for Statistics (2007) Institute for Statistics Online Database, http://stats.uis.unesco.org/.

World Bank (2006) Africa Database 2006, CDROM (Washington, D.C.: World Bank).

World Bank (2007) World Development Indicators Online Database, www.worldbank.org/data/. 


\section{Appendix I - Data}

\section{Sample:}

Angola, Benin, Botswana, Burkina Faso, Burundi, Cameroon, Central African Republic, Chad, Republic of Congo, Cote d'Ivoire, Ethiopia, Gabon, The Gambia, Ghana, Guinea, Guinea-Bissau, Kenya, Lesotho, Madagascar, Malawi, Mali, Mauritania, Mauritius, Mozambique, Namibia, Niger, Nigeria, Rwanda, Senegal, Seychelles, South Africa, Sudan, Swaziland, Tanzania, Togo, Uganda, Zambia, Zimbabwe

\section{Sub-samples based on resource-intensity:}

These groupings follows Collier and O'Connell (2006) who classifies a country as resource-rich if primary commodity rents exceed 10 per cent of GDP.

\section{Resource-intensive:}

- Angola, Cameroon, Chad, Republic of Congo, Gabon, Nigeria (oil)

- Botswana, Cote d'Ivoire, Guinea, Namibia, Zambia (non-oil)

\section{Non-resource-intensive:}

- Benin, Burkina Faso Burundi, Central African Republic, Ethiopia, The Gambia, Ghana, Guinea-Bissau, Kenya, Lesotho, Madagascar, Malawi, Mali, Mauritania, Mauritius, Mozambique, Niger, Rwanda, Senegal, Seychelles, South Africa, Sudan, Swaziland, Tanzania, Togo, Uganda, Zambia, Zimbabwe 


\section{Variables:}

\begin{tabular}{|c|c|c|}
\hline Variable name & Description & Source \\
\hline FDI/GDP & $\begin{array}{l}\text { Inflows of foreign direct investment as a ratio } \\
\text { of real GDP }\end{array}$ & UNCTAD (2007) \\
\hline GDP growth & Real GDP growth (annual \%) & World Bank (2007) \\
\hline Openness & Exports plus imports/GDP & World Bank (2007) \\
\hline $\begin{array}{l}\text { Log of telephone } \\
\text { subscribers }\end{array}$ & $\begin{array}{l}\text { Telephone subscribers = fixed line plus mobile } \\
\text { subscribers }\end{array}$ & World Bank (2007) \\
\hline Log of FDI stock & Log of inward stock of FDI, US\$ million & UNCTAD (2007) \\
\hline Detrended REER & $\begin{array}{l}\text { Real effective exchange rate }(2000=100) \text {, } \\
\text { detrended with linear time trend }\end{array}$ & World Bank (2007) \\
\hline REER volatility & $\begin{array}{l}\text { REER volatility=absolute value of REER - } \\
\text { detrended REER }\end{array}$ & World Bank (2007) \\
\hline Detrended CPI & $\begin{array}{l}\text { Inflation, consumer prices (annual \%), } \\
\text { detrended with linear time trend }\end{array}$ & World Bank (2007) \\
\hline CPI volatility & $\begin{array}{l}\text { CPI volatility= absolute value of CPI- } \\
\text { detrended CPI }\end{array}$ & World Bank (2007) \\
\hline Polity score & $\begin{array}{l}\text { Combined polity score, ranges from }-10 \\
\text { (strongly autocratic) to }+10 \text { (strongly } \\
\text { democratic) }\end{array}$ & Polity IV Project \\
\hline $\begin{array}{l}\text { Oil, mineral and ore } \\
\text { exports as \% of total } \\
\text { merchandise exports }\end{array}$ & $\begin{array}{l}\text { Oil, mineral and ore exports as \% of total } \\
\text { merchandise exports }\end{array}$ & World Bank (2007) \\
\hline Ogive concentration index & Ogive concentration index & UNECA (2007) \\
\hline Private investment/GDP & Private investment as a ratio of real GDP & World Bank (2006) \\
\hline Public investment/GDP & Public investment as a ratio of real GDP & World Bank (2006) \\
\hline Youth literacy rate & Youth population are defined as 15-24 & UNESCO (2007) \\
\hline
\end{tabular}




\section{Appendix II - Tables}

Table A1: Summary Statistics - FDI, private and public investment

\begin{tabular}{|c|c|c|c|}
\hline Country & FDI/GDP & PRIV/GDP & PUB/GDP \\
\hline Angola & 6.93 & 12.25 & 6.07 \\
\hline Benin & 1.18 & 8.60 & 7.52 \\
\hline Botswana & 2.32 & 21.18 & 12.65 \\
\hline Burkina Faso & 0.27 & 11.65 & 8.58 \\
\hline Burundi & 0.19 & 1.86 & 10.71 \\
\hline Cameroon & 0.40 & 16.89 & 4.13 \\
\hline Central African & 0.39 & 4.90 & 5.73 \\
\hline Chad & 6.16 & 8.08 & 6.85 \\
\hline Congo, Rep. & 3.45 & 15.88 & 7.92 \\
\hline Cote d'Ivoire & 1.30 & 9.69 & 6.58 \\
\hline Ethiopia & 1.29 & 12.51 & 5.64 \\
\hline Gabon & 0.57 & 23.21 & 9.61 \\
\hline The Gambia & 2.79 & 10.81 & 8.82 \\
\hline Ghana & 1.38 & 8.48 & 9.26 \\
\hline Guinea & 0.99 & 10.43 & 6.60 \\
\hline Guinea-Bissau & 1.09 & 6.78 & 20.51 \\
\hline Kenya & 0.37 & 9.70 & 6.27 \\
\hline Lesotho & 2.35 & 33.86 & 15.60 \\
\hline Madagascar & 0.50 & 6.06 & 7.13 \\
\hline Malawi & 0.93 & 6.02 & 10.59 \\
\hline Mali & 1.25 & 12.72 & 9.43 \\
\hline Mauritania & 1.68 & 13.07 & 7.76 \\
\hline Mauritius & 0.80 & 18.63 & 5.62 \\
\hline Mozambique & 2.32 & 12.59 & 10.83 \\
\hline Namibia & 3.40 & 11.45 & 9.03 \\
\hline Niger & 0.84 & 3.64 & 8.31 \\
\hline Nigeria & 2.46 & 9.84 & 9.30 \\
\hline Rwanda & 0.50 & 8.21 & 9.65 \\
\hline Senegal & 0.85 & 8.88 & 5.03 \\
\hline Seychelles & 5.21 & 15.52 & 10.59 \\
\hline South Africa & 0.55 & 10.03 & 7.07 \\
\hline Sudan & 1.58 & 11.42 & 3.87 \\
\hline Swaziland & 3.78 & 15.90 & 7.59 \\
\hline Tanzania & 2.23 & 12.46 & 5.83 \\
\hline Togo & 1.66 & 11.23 & 6.60 \\
\hline Uganda & 1.65 & 10.07 & 5.28 \\
\hline Zambia & 2.80 & 6.68 & 8.14 \\
\hline Zimbabwe & 0.59 & 14.13 & 2.54 \\
\hline
\end{tabular}

Notes: FDI/GDP = foreign direct investment/GDP; PRIV/GDP = gross private investment/GDP; PUB/GDP = gross public investment/GDP.

Source: UNCTAD, FDI online database; World Bank Africa Database 2006; World Development Indicators, online database. 